\title{
The Effect of Vitamin A on Contraction of the Ductus Arteriosus in Fetal Rat
}

\author{
GUI-RONG WU, SHEN JING, KAZUO MOMMA, AND TOSHIO NAKANISHI \\ Department of Pediatric Cardiology, The Heart Institute of Japan, Tokyo Women's Medical University, \\ Tokyo, 162 Japan
}

\begin{abstract}
ABST
Endogenous retinoic acid may play a role in inducing smooth
muscle differentiation in the fetal ductus arteriosus. Maternal
administration of retinoic acid may accelerate the process. This
study was designed to investigate the effect of vitamin A on
developmental changes in the contractile system of the ductus.
Vitamin A was injected into pregnant rats and the ductus was
isolated from the fetus at 19,20 , or 21 d of gestation. The fetus
at 19 d of gestation served as a model of the preterm fetus. The
force of contraction and $[\mathrm{Ca}]_{\mathrm{i}}$ were measured. Membrane depo-
larization caused by high $\mathrm{KCl}$ induced ductal contraction in all
age groups studied. In the $19-\mathrm{d}$ fetus, $\mathrm{O}_{2}$ did not cause significant
contraction or changes in $[\mathrm{Ca}]_{\mathrm{i}}$ in the control group, but it did
induce a significant contraction and increases in $[\mathrm{Ca}]_{\mathrm{i}}$ in the
vitamin A-treated group. In the 20 - and $21-\mathrm{d}$ fetuses, $5 \% \mathrm{O}_{2}-$
induced contraction in the vitamin A-treated group was signifi-
cantly greater than in the control group. In the $19-\mathrm{d}$ fetus,
noradrenaline-induced contraction and increases in $[\mathrm{Ca}]_{\mathrm{i}}$, indica-
\end{abstract}
tors of the size of the intracellular $\mathrm{Ca}$ pool, were observed and they were similar in the control group and in the vitamin Atreated group. These data suggest that 1 ) in the preterm fetus, the contractile system, including membrane depolarization, [Ca]i increase, and its activation of contractile proteins, is already functioning, but the $\mathrm{O}_{2}$-sensing mechanism is underdeveloped, 2) vitamin $\mathrm{A}$ accelerates the development of the $\mathrm{O}_{2}$-sensing mechanism of the ductus arteriosus. (Pediatr Res 49: 747-754, 2001)

Abbreviations:
DA, ductus arteriosus
Ca, calcium
K, potassium
[Ca]I, intracellular Ca concentration
fura-2/AM, fura-2/acetoxymethyl ester

The ductus arteriosus (DA) normally closes after birth. Increases in arterial $\mathrm{PO}_{2}$, decreases in endogenous dilator prostaglandins and nitric oxide, and/or production of endothelin-1 may be responsible for the ductal closure (1-4).

Failure of the DA to close after birth is more frequent in premature than in mature infants. In full-term neonates, closure of the DA occurs in two phases after birth: 1) initial muscular constriction, and 2) neointimal thickening after mechanical closure. Both muscular constriction and neointimal thickening may be inadequate in premature neonates (5). Indomethacin, a prostaglandin synthetase inhibitor, has been used clinically to induce ductal closure, but its effect is minimal before $24 \mathrm{wk}$ of

Received January 11, 2000; accepted May 3, 2000.

Correspondence: Toshio Nakanishi, MD, Department of Pediatric Cardiology, The Heart Institute of Japan, Tokyo Women's Medical University, 8-1 Kawadacho, Shinjuku, Tokyo, 162, Japan; e-mail: pnakanis@hij.twmu.ac.jp

Supported by a Research Grant 11671076 from the Japanese Ministry of Education, Science, and Culture, and a grant-in-aid from the Japan Research Promotion Society for Cardiovascular Diseases. gestation in humans $(6,7)$. In an in situ morphometric analysis in rats, Momma et al. (8-10) showed that maternal administration of indomethacin caused only mild DA constriction at $19 \mathrm{~d}$ of gestation and strong constriction in the near-term fetus at $21 \mathrm{~d}$ of gestation. The precise mechanisms by which the DA in premature infants or animals is resistant to vasoconstrictive stimulation remain unclear.

Kim et al. (11) have shown in near-term fetal rabbits that the expression of the adult type isoform of smooth muscle myosin heavy chain in the DA was more prominent than in other arteries. They suggested that vascular smooth muscle cells might be more differentiated in the DA than in other arteries. Colbert et al. (12) showed that endogenous retinoic acid signaling colocalized with advanced expression of the adult type of smooth muscle myosin heavy chain isoform during development of the DA. These authors speculated that retinoic acid might play a role in inducing and maintaining smooth muscle differentiation. Momma et al. (9) hypothesized that exogenously administered retinoic acid might accelerate maturation 
of the fetal DA, and they, indeed, showed that maternally administered vitamin A enhanced indomethacin-induced DA constriction in in situ morphometric analysis. The mechanisms underlying acceleration of ductal constriction by vitamin A, however, remained unclear.

The purpose of the present study was to clarify 1 ) developmental changes in the contractile system of the DA and 2) the effect of vitamin A treatment on the contractile system of the DA using a ductal preparation isolated from the fetal rat.

Previous studies have suggested that $\mathrm{O}_{2}$-induced contraction of the DA is, at least partly, induced by membrane depolarization, which then results in increases in $[\mathrm{Ca}]_{\mathrm{i}}(13,14)$. Since extracellular $\mathrm{Ca}$ was required for the increase in $[\mathrm{Ca}]_{\mathrm{i}}(13)$, an increase in $\mathrm{Ca}$ influx across the sarcolemma is probably the main mechanism for the increase in $[\mathrm{Ca}]_{\mathrm{i}}$, but $\mathrm{Ca}$-induced $\mathrm{Ca}$ release from intracellular store sites may also occur. In the present study, the effect of $\mathrm{O}_{2}$ on DA contraction and $[\mathrm{Ca}]_{\mathrm{i}}$ was studied in mature as well as premature fetuses. To induce membrane depolarization, high $\mathrm{K}$ was used and the effect of high $\mathrm{KCl}$ on ductal contraction and $[\mathrm{Ca}]_{\mathrm{i}}$ was measured. The size of the intracellular $\mathrm{Ca}$ pool was examined using norepinephrine, which releases $\mathrm{Ca}$ from intracellular store sites (15-17).

\section{MATERIALS AND METHODS}

Animals. Wistar virgin rats were mated overnight from 1700 to $900 \mathrm{~h}$. The presence of sperm in vaginal smears was confirmed as day 0 of pregnancy (pregnancy period $21.5 \mathrm{~d}$ ). All rats were fed commercial solid food (Labo RUM Breeder, Nippon-Nousan Co., Ltd., Yokohama, Japan) and water. The food contained $1200 \mathrm{IU}$ of vitamin A per $100 \mathrm{~g}$, as specified by the manufacturer. All animals were cared for in compliance with the guiding principles of the American Physiologic Society. The experiments were approved by the Ethical Committee of Animal Experiments of our Institute.

Vitamin A Administration. Retinyl palmitate (Eisai Co. Ltd, Tokyo, Japan), $33 \mathrm{mg}$, which is equivalent to $18 \mathrm{mg}$ of retinol (vitamin A, 50,000 IU), was dissolved in safflower seed oil (Nissinseiyu Co, Ltd., Tokyo, Japan) to a concentration of 1.8 $\mathrm{mg}$ of retinol $/ \mathrm{mL}$. The vitamin A solution was injected intramuscularly into the dorsum of pregnant rats at $900 \mathrm{~h}$ on the 17 th, 18th, 19th, or 20th days of gestation at a dose of $1 \mathrm{mg}$ $(3000 \mathrm{IU}) / \mathrm{kg}$ of body weight. The dose of vitamin A used in the present study was chosen to be within the therapeutic range for latent deficiency, as described previously (9). Experiments were performed using the ductus arteriosus isolated from the fetal rat at 19,20 , or $21 \mathrm{~d}$ of gestation. When vitamin A was administered once, it was injected 1 day before the experiment. When vitamin A was administered twice, it was injected 1 and 2 days before the experiment. In the control group, safflower seed oil only was injected into pregnant rats in a similar fashion described above.

Experimental Preparation. After the doe was anesthetized with pentobarbital sodium $(50 \mathrm{mg} / \mathrm{kg})$, the fetuses were delivered by cesarean section. The ductal tissue was excised from the chest cavity using a dissecting microscope (model SMA, Nikon, Tokyo, Japan). The isolated ductus arteriosus was placed in a HEPES-buffered solution equilibrated with room air. The surrounding tissues were removed under a dissecting microscope. The ductus preparation was placed in a tissue bath and kept at $37^{\circ} \mathrm{C}$. Two tungsten wires $(25 \mu \mathrm{m}$ in diameter, Thermonic Products Company, North Plainfield, NJ, U.S.A.) were threaded into the lumen and the preparation was placed in a myograph (Living Systems, Burlington, VT, U.S.A.) (16, $18-20$ ). The tungsten wires were secured by stainless screws to specially designed holders. One holder was connected to a micro-manipulator and the other was connected to a force transducer (Kulite Semiconductor, Leonia, NJ, U.S.A.). Isometric tension was monitored using the force transducer and a recorder (San-ei Sokki, Tokyo, Japan). When set up, the preparation was superfused with solutions at $20 \mathrm{~mL} / \mathrm{min}$. For $[\mathrm{Ca}]_{\mathrm{i}}$ determination, the ductus preparation was placed in a tissue bath that was mounted on the stage of an inverted microscope (model TMD, Nikon). All ductus rings were initially stabilized for $30 \mathrm{~min}$ with hypoxic Krebs-Henseleit solution at $37^{\circ} \mathrm{C}$ equilibrated with $5 \% \mathrm{CO}_{2}$ and $95 \% \mathrm{~N}_{2}$.

Axial length, outer diameter, and inner diameter of the preparation were measured before it was stretched, and the muscle volume $(\mathrm{V}),\left(\mathrm{mm}^{3}\right)$, was calculated assuming that the shape of the preparation was cylindrical. Axial vessel length $(\mathrm{L})$, the distance between the wires (D), and force (F) were measured while the vessel was stretched gradually. The wall thickness $(\mathrm{H})$ at the time of force measurement was calculated as: $\mathrm{H}=\mathrm{V} / 2 \mathrm{LD}$. The wall tension, expressed as $\mathrm{mN} / \mathrm{mm}(16$, 21,22 ), was calculated as: wall tension $=\mathrm{F} / 2 \mathrm{~L}$. The contractile force, normalized by the cross-sectional area of the preparation, was also calculated as: wall stress $\left(\mathrm{mN} / \mathrm{mm}^{2}\right)=\mathrm{F} / 2 \mathrm{LH}$. The resting tension was adjusted to $0.35-0.5 \mathrm{mN} / \mathrm{mm}$ (mean $0.40 \pm 0.05)$ in the fetus at $19 \mathrm{~d}$ of gestation, $0.4-0.7 \mathrm{mN} / \mathrm{mm}$ (mean $0.55 \pm 0.08$ ) at $20 \mathrm{~d}$ of gestation, and $0.6-0.8 \mathrm{mN} / \mathrm{mm}$ (mean $0.72 \pm 0.09$ ) at $21 \mathrm{~d}$ of gestation. In a preliminary study, the resting tension/developed tension relation was examined and at these values of resting tension, developed tension (total tension/resting tension) induced by $50 \mathrm{mM} \mathrm{KCl}$ was $80 \%$ of the maximal level. These values of resting tension were chosen to avoid any over-stretching of the vessel.

Solution. The control Krebs-Henseleit solution contained (in $\mathrm{mM}$ ): $\mathrm{NaCl}, 118 ; \mathrm{KCl}, 5 ; \mathrm{CaCl}_{2}, 1.5 ;$ glucose, $6 ; \mathrm{MgCl}_{2}, 1$; $\mathrm{NaHCO}_{3}, 24$; and $\mathrm{NaH}_{2} \mathrm{PO}_{4}, 0.436$. The solution was equilibrated with one of the following gasses: $95 \% \mathrm{~N}_{2}-5 \% \mathrm{CO}_{2}$ $\left(\mathrm{Po}_{2}=22-25 \mathrm{~mm} \mathrm{Hg}\right.$, solution \#1), 5\% $\mathrm{O}_{2}-90 \% \mathrm{~N}_{2}-5 \% \mathrm{CO}_{2}$ $\left(\mathrm{Po}_{2}=57-60 \mathrm{~mm} \mathrm{Hg}\right.$, solution \#2), 30\% $\mathrm{O}_{2}-65 \% \mathrm{~N}_{2}-5 \%$ $\mathrm{CO}_{2}\left(\mathrm{Po}_{2}=218-232 \mathrm{~mm} \mathrm{Hg}\right.$, solution $\left.\# 3\right)$, or $95 \% \mathrm{O}_{2}-5 \%$ $\mathrm{CO}_{2}\left(\mathrm{PO}_{2}=660-690 \mathrm{~mm} \mathrm{Hg}\right.$, solution \#4). The final $\mathrm{pH}$ was 7.38-7.42 and $\mathrm{PCO}_{2}$ was $35-42 \mathrm{~mm} \mathrm{Hg}$ in all solutions.

The HEPES solution contained (in $\mathrm{mM}$ ): $\mathrm{NaCl}, 142 ; \mathrm{KCl}, 5$; $\mathrm{CaCl}_{2}, 1.5$; glucose, 6 ; $\mathrm{MgCl}_{2}, 1$; HEPES, 5 ; $\mathrm{pH} 7.4$ with $1 \mathrm{M}$ $\mathrm{NaOH}$. The HEPES solution was equilibrated with either $100 \%$ $\mathrm{N}_{2}$ or $100 \% \mathrm{O}_{2}\left(\mathrm{Po}_{2}=22-25\right.$ or $790-810 \mathrm{~mm} \mathrm{Hg}$, respectively). In potassium-enriched solutions (50 or $120 \mathrm{mM})$, the $\mathrm{NaCl}$ was replaced, mol by mol, with $\mathrm{KCl}$. The Ca-and $\mathrm{Na}$-free solution contained in $\mathrm{mM}$ : N-methylglucamine, $142 ; \mathrm{KCl}, 4$; K2-EGTA, 1; glucose, 6 ; $\mathrm{MgCl}_{2}$, 1; HEPES, 5; $\mathrm{pH} 7.4$ with 1 $\mathrm{M} \mathrm{HCl}$. 
Ductal Contraction. Ductal contraction was induced by four methods: $\mathrm{O}_{2}$, indomethacin, noradrenaline, and $50 \mathrm{mM} \mathrm{KCl}$. In experiments in which ductal contraction was induced by $\mathrm{O}_{2}$, hypoxic Krebs-Henseleit solution \#1 was changed to solution $\# 2\left(5 \% \mathrm{O}_{2}\right)$, solution \#3 $\left(30 \% \mathrm{O}_{2}\right)$, and then to solution \#4 $\left(95 \% \mathrm{O}_{2}\right)$. After the force reached a new steady state, the solution was again returned to the hypoxic solution. In all experiments, ductal contraction was finally induced by $50 \mathrm{mM}$ $\mathrm{KCl}$ under hypoxic conditions. The $50 \mathrm{mM} \mathrm{KCl}$ was used to induce moderate membrane depolarization. In some experiments, however, ductal contraction was induced by $120 \mathrm{mM}$ $\mathrm{KCl}+10 \mathrm{mM} \mathrm{CaCl}$ to examine the degree of maximal contraction.

In additional experiments, the role of the endothelium in an age-related difference in the effect of $\mathrm{O}_{2}$ was studied. The endothelium was removed by gently rubbing the internal wall of the vessel with a polyethylene tube (PE-50), which had been tapered to $50-100 \mu \mathrm{m}$ in diameter. At the end of the experiments, all the ductal preparations were fixed in $10 \%$ formalin and the absence of the endothelium was confirmed histologically.

In experiments in which ductal contraction was induced by indomethacin, hypoxic Krebs-Henseleit solution \#1 $\left(0 \% \mathrm{O}_{2}\right)$, was changed to solution $\# 2\left(5 \% \mathrm{O}_{2}\right)$, to partially activate the $\mathrm{O}_{2}$-sensitive mechanisms of ductal contraction. The solution was then changed to solution $\# 2$ containing $10^{-6} \mathrm{M}$ of indomethacin. This concentration of indomethacin inhibits cyclooxygenase activity completely $(23,24)$. In some experiments, the indomethacin concentration was increased to $3 \times 10^{-6} \mathrm{M}$.

The size of the intracellular Ca pool was examined using norepinephrine. Norepinephrine increases $\mathrm{Ca}$ influx via $\mathrm{Ca}$ channels by stimulating beta-receptors, and releases $\mathrm{Ca}$ from intracellular store sites by stimulating alpha-receptors (15-17). To eliminate the $\mathrm{Ca}$ influx via the $\mathrm{Ca}$ channel and $\mathrm{Ca}$ efflux via $\mathrm{Na}-\mathrm{Ca}$ exchange, the effect of norepinephrine was examined in the absence of extracellular $\mathrm{Na}$ and $\mathrm{Ca}$ (16). Initially, the vessel was superfused with a control HEPES solution equilibrated with $100 \% \mathrm{~N}_{2}$. The vessel was then superfused with a HEPES solution that did not contain $\mathrm{Ca}$ and $\mathrm{Na}$. Ten minutes after superfusion with the $\mathrm{Ca}$-and $\mathrm{Na}$-free solution, the vessel was superfused with the Ca-and $\mathrm{Na}$-free solution containing $10^{-5} \mathrm{M}$ noradrenaline. After the developed tension reached its peak value, the vessel was superfused again with a control HEPES solution. After the mechanical function returned to control, vascular contraction was induced by a solution containing 50
$\mathrm{mM} \mathrm{KCl}$. The degree of noradrenaline-induced contraction was normalized by the degree of $\mathrm{KCl}$-induced contraction. Since norepinephrine may alter the sensitivity of contractile proteins to $\mathrm{Ca}$, the effect of norepinephrine on intracellular $\mathrm{Ca}$ concentrations was also measured.

Fluorescence Measurements. $[\mathrm{Ca}]_{\mathrm{i}}$ of the ductal tissue was measured using fura-2, as described previously $(13,25,26)$. In brief, a mixture was made of $60 \mu \mathrm{L}$ of $1 \mathrm{mM}$ fura-2/AM in DMSO, $20 \mu \mathrm{L}$ of $25 \%$ cremophor and $240 \mu \mathrm{L}$ of FCS. The mixture was added to $5 \mathrm{~mL}$ HEPES solution and mixed well. The ductus preparation was then superfused with the solution equilibrated with $100 \% \mathrm{~N}_{2}$ for $1-2 \mathrm{~h}$ at room temperature $\left(22-24^{\circ} \mathrm{C}\right)$. After the dye loading, the ductus preparation was superfused for $30 \mathrm{~min}$ with dye-free solutions to wash out extracellular fluorescent dye. Excitation lights of 340 and 380 $\mathrm{nm}$ wavelengths were obtained alternatively using a xenon lamp (450-W), two monochrometers, and a chopper (Spex, Edison, NJ, U.S.A.). The emitted light passed through a $505 \mathrm{~nm}$ band-pass filter and its intensity was measured by a photomultiplier (Hamamatsu Photonics R928, Hamamatsu, Japan). The intensity of fura-2 fluorescence at $505 \mathrm{~nm}$ during excitation at each wavelength was observed for $1 \mathrm{~s}$ at 5 -s intervals. The interval between acquisition of the $340 \mathrm{~nm}$ excitation and that of the $380 \mathrm{~nm}$ excitation was $1 \mathrm{~s}$. The fura-2 fluorescence ratio was then calculated as follows: ratio $=$ (fluorescence at $340 \mathrm{~nm}$ excitation-autofluorescence at $340 \mathrm{~nm}$ excitation)/(fluorescence at $380 \mathrm{~nm}$ excitation-autofluorescence at $380 \mathrm{~nm}$ excitation).

Fura-2 and fura-2/AM were purchased from Dojin Chemical Co. (Kumamoto, Japan). DMSO was purchased from EastmanKodak. Fura-2 and fura-2/AM were dissolved in DMSO to 1 $\mathrm{mM}$. Cremophor EL (Sigma Chemical Co.) was diluted to $25 \%$ with DMSO.

Statistical Analysis. Results were expressed as mean \pm SE. One-way analysis of variance was used for multiple comparisons. Statistical significance of difference between group means was determined using Dunnett $t$ test. Percent changes were compared using the nonparametric method (Wilcoxon's rank sum test) (27). The statistical significance of response to vasoconstrictive stimulations was analyzed using a paired $t$ test and repeated measurements of analysis of variance. A difference was considered statistically significant when $P$ was less than 0.05 .

Table 1. Body weight of fetuses and size of ductus arteriosus

\begin{tabular}{|c|c|c|c|c|c|c|c|}
\hline Age groups & Pre-treatment & $n$ & $\begin{array}{l}\text { Body weight } \\
(\mathrm{g})\end{array}$ & $\begin{array}{l}\text { Ductal length } \\
(\mathrm{mm})\end{array}$ & $\begin{array}{l}\text { Inner diameter } \\
(\mathrm{mm})\end{array}$ & $\begin{array}{l}\text { Outer diameter } \\
\qquad(\mathrm{mm})\end{array}$ & $\begin{array}{c}\text { Wall thickness } \\
\text { (mm) }\end{array}$ \\
\hline 1. 19-day fetus & Control & 24 & $2.1 \pm 0.1$ & $0.42 \pm 0.04$ & $0.13 \pm 0.01$ & $0.38 \pm 0.01$ & $0.25 \pm 0.01$ \\
\hline 2. 19-day fetus & Vitamin A (once) & 9 & $2.0 \pm 0.2$ & $0.47 \pm 0.14$ & $0.12 \pm 0.02$ & $0.39 \pm 0.02$ & $0.27 \pm 0.01$ \\
\hline 3. 19-day fetus & Vitamin A (twice) & 26 & $2.1 \pm 0.1$ & $0.48 \pm 0.07$ & $0.13 \pm 0.01$ & $0.38 \pm 0.02$ & $0.25 \pm 0.01$ \\
\hline 4. 20-day fetus & Control & 10 & $2.8 \pm 0.2$ & $0.49 \pm 0.06$ & $0.12 \pm 0.02$ & $0.42 \pm 0.01$ & $0.30 \pm 0.01$ \\
\hline 5. 20-day fetus & Vitamin A (once) & 6 & $2.8 \pm 0.3$ & $0.51 \pm 0.03$ & $0.12 \pm 0.01$ & $0.43 \pm 0.01$ & $0.31 \pm 0.01$ \\
\hline 6. 20-day fetus & Vitamin A (twice) & 11 & $2.9 \pm 0.2$ & $0.52 \pm 0.02$ & $0.12 \pm 0.01$ & $0.41 \pm 0.01$ & $0.29 \pm 0.01$ \\
\hline 7. 21-day fetus & Control & 5 & $4.2 \pm 0.3$ & $0.59 \pm 0.05$ & $0.18 \pm 0.01$ & $0.50 \pm 0.06$ & $0.32 \pm 0.02$ \\
\hline 8. 21-day fetus & Vitamin A (once) & 5 & $4.3 \pm 0.6$ & $0.60 \pm 0.02$ & $0.18 \pm 0.03$ & $0.51 \pm 0.05$ & $0.33 \pm 0.02$ \\
\hline 9. 21-day fetus & Vitamin A (twice) & 5 & $4.3 \pm 0.7$ & $0.60 \pm 0.02$ & $0.19 \pm 0.01$ & $0.53 \pm 0.04$ & $0.34 \pm 0.01$ \\
\hline
\end{tabular}


Table 2. Force of contraction induced by $50 \mathrm{mM} \mathrm{KCl}$

\begin{tabular}{llrcc}
\hline Age groups & Pre-treatment & $n$ & $\begin{array}{c}\text { Contractile force } \\
(\mathrm{mN} / \mathrm{mm})\end{array}$ & $\begin{array}{c}\text { Contractile force } \\
\left(\mathrm{mN} / \mathrm{mm}^{2}\right)\end{array}$ \\
\hline 1. 19-day fetus & Control & 24 & $0.76 \pm 0.06$ & $15.7 \pm 1.3$ \\
2. 19-day fetus & Vitamin A (once) & 9 & $0.88 \pm 0.06$ & $17.1 \pm 1.3$ \\
3. 19-day fetus & Vitamin A (twice) & 26 & $0.84 \pm 0.07$ & $15.8 \pm 1.6$ \\
4. 20-day fetus & Control & 10 & $1.12 \pm 0.08^{*}$ & $14.7 \pm 1.0$ \\
5. 20-day fetus & Vitamin A (once) & 6 & $1.27 \pm 0.08^{*}$ & $16.4 \pm 1.2$ \\
6. 20-day fetus & Vitamin A (twice) & 11 & $1.15 \pm 0.08^{*}$ & $15.4 \pm 1.0$ \\
7. 21-day fetus & Control & 5 & $1.47 \pm 0.13 \dagger$ & $1.00 \pm 1.4$ \\
8. 21-day fetus & Vitamin A (once) & 5 & $1.40 \pm 0.12$ & $14.7 \pm 1.2$ \\
9. 21-day fetus & Vitamin A (twice) & 5 & $1.61 \pm 0.14 \dagger$ & $17.2 \pm 1.6$ \\
\hline
\end{tabular}

* Significantly different from the value in the 19-day fetus.

$\dagger$ Significantly different from the value in the 20-day fetus.

\section{RESULTS}

Body weight in the fetuses with vitamin A treatment was not significantly different from that in the control fetuses. Length, outer diameter, and inner diameter of the ductus isolated from the fetuses with vitamin A treatment were similar to those in the control fetuses (Table 1).

KCl-Induced Contraction. Membrane depolarization caused by high $\mathrm{KCl}(50 \mathrm{mM})$ induced ductal contraction in all age groups studied. The developed tension expressed as $\mathrm{mN} / \mathrm{mm}$ increased with age (Table 2). The contractile force normalized by the cross-sectional area, however, did not change with age. In each age group, the $\mathrm{KCl}$-induced contraction in the fetuses treated with vitamin A was not significantly different from that in the control group.

Maximal contraction was also induced by $120 \mathrm{mM} \mathrm{KCl}+$ $10 \mathrm{mM} \mathrm{CaCl}_{2}$ in the fetuses at 19 and $21 \mathrm{~d}$ of gestation. Ductal contraction induced by $50 \mathrm{mM} \mathrm{KCl}$ was $83 \%$ to $85 \%$ of the maximal contraction induced by $120 \mathrm{mM} \mathrm{KCl}+10 \mathrm{mM} \mathrm{CaCl}_{2}$

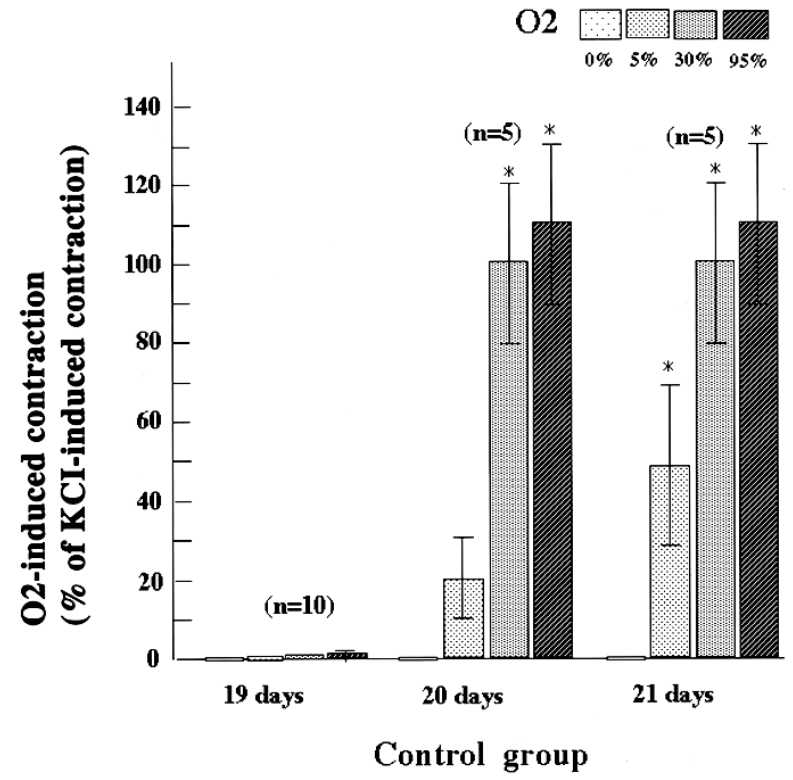

Figure 1. Graph showing the effect of $\mathrm{O}_{2}$ on ductal contraction, expressed as a relative value of $50 \mathrm{mM} \mathrm{KCl}$-induced contraction, in the control fetuses. In the fetus at $19 \mathrm{~d}$ of gestation, $\mathrm{O}_{2}$ did not cause significant contraction. In the control fetus at $20 \mathrm{~d}$ of gestation, $30 \%$ and $95 \% \mathrm{O}_{2}$, but not $5 \% \mathrm{O}_{2}$, induced significant contraction. In the control fetus at $21 \mathrm{~d}$ of gestation, $5 \%$ to $95 \% \mathrm{O}_{2}$ caused significant contraction. *Significant contraction. in all age groups studied, and in each age group, the maximal contraction in the fetus treated with vitamin A twice was not significantly different from that in the control fetus.

$\mathrm{O}_{2}$-Induced Contraction. The degree of $\mathrm{O}_{2}$-induced contraction was expressed as a relative value of $50 \mathrm{mM} \mathrm{KCl}-$ induced contraction (Fig. 1). In the control fetus at $19 \mathrm{~d}$ of gestation, $\mathrm{O}_{2}$ did not cause significant contraction. In the control fetus at $20 \mathrm{~d}$ of gestation, $30 \%$ and $95 \%$, but not $5 \% \mathrm{O}_{2}$, induced significant contraction. In the control fetus at $21 \mathrm{~d}$ of gestation, $5 \%$ to $95 \% \mathrm{O}_{2}$ caused significant contraction.

In the fetus at $19 \mathrm{~d}$ of gestation, which was treated with vitamin A once or twice, $5 \%$ to $95 \% \mathrm{O}_{2}$ induced a small but significant contraction (Fig. 2).

In the fetus at $20 \mathrm{~d}$ of gestation, $30 \%$ and $95 \% \mathrm{O}_{2}$ caused significant contraction in both the control fetus and the vitamin A-treated fetus (Fig. 3). $\mathrm{O}_{2}(5 \%)$ caused significant contraction only in the fetus treated with vitamin A twice.

In the fetus at $21 \mathrm{~d}$ of gestation, $5 \%$ to $95 \% \mathrm{O}_{2}$ caused significant contraction in both the control and vitamin Atreated groups (Fig. 4). In the fetus treated with vitamin A twice, contraction induced by $5 \% \mathrm{O}_{2}$ was significantly greater than in the control group.

Indomethacin-Induced Contraction. The effect of indomethacin was studied in the fetus at $19 \mathrm{~d}$ of gestation. Indo-

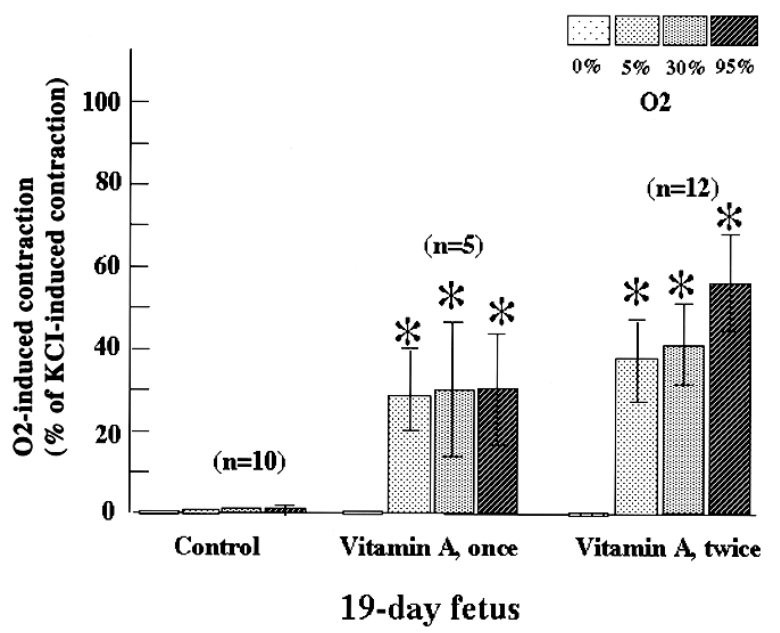

Figure 2. Graph showing the effect of ductal contraction in the fetus at $19 \mathrm{~d}$ of gestation. In the group treated with vitamin A once or twice, $5 \%$ to $95 \% \mathrm{O}_{2}$ induced a small but significant contraction. *Significant contraction. 


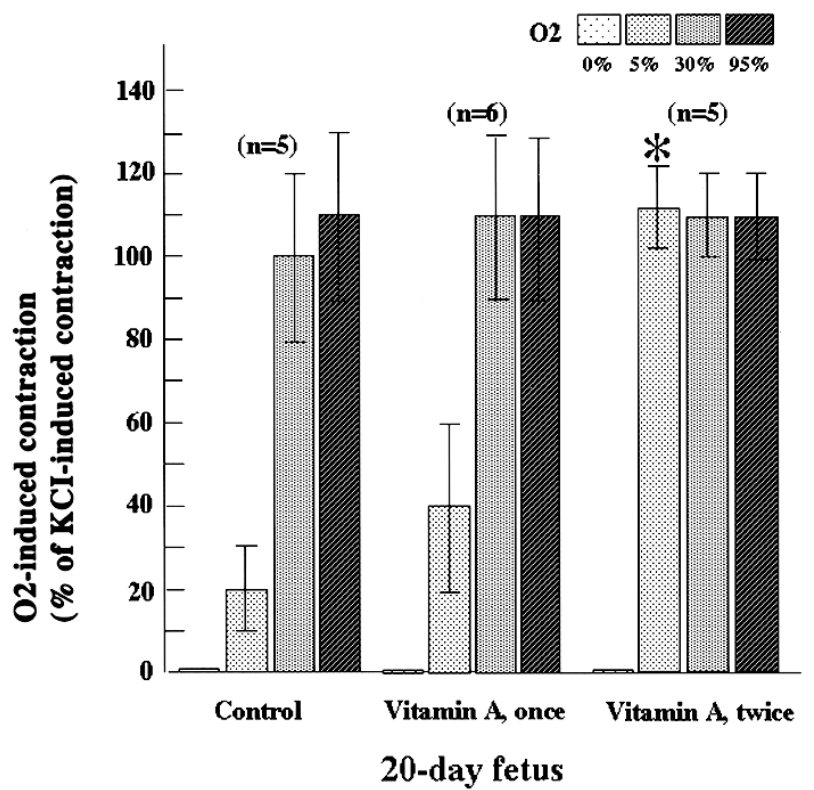

Figure 3. Graph showing the effect of $\mathrm{O}_{2}$ on the ductus in the fetus at $20 \mathrm{~d}$ of gestation. Thirty percent and $95 \% \mathrm{O}_{2}$ caused significant contraction in both the control fetus and the vitamin A-treated fetus, while 5\% $\mathrm{O}_{2}$ caused significant contraction only in the fetus treated with vitamin A twice. *Significantly different from the value in the control group.

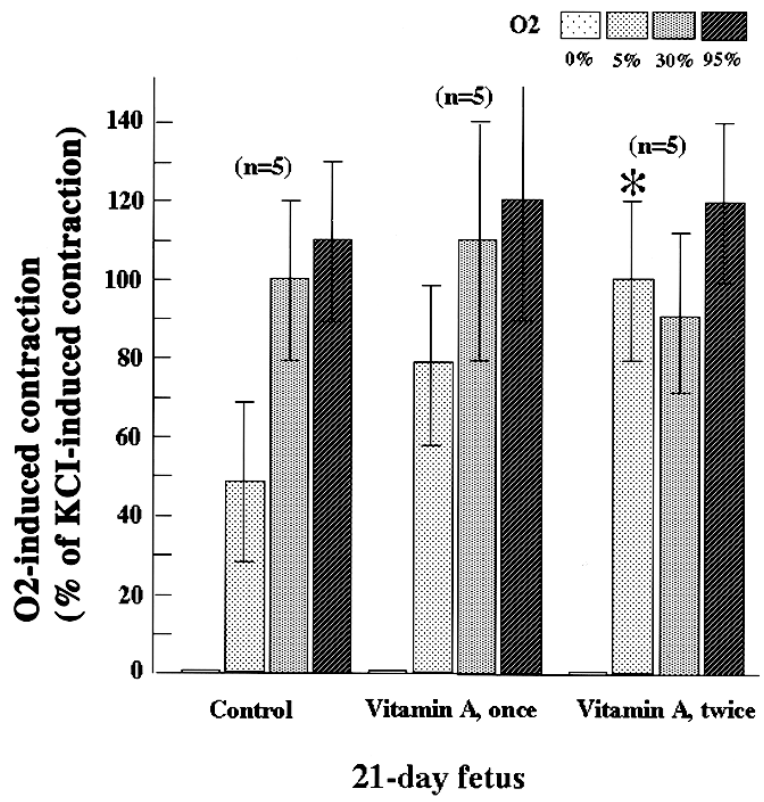

Figure 4. Graph showing the effect of $\mathrm{O}_{2}$ on ductal contraction in the fetus at $21 \mathrm{~d}$ of gestation. In all groups, $5 \%$ to $95 \% \mathrm{O}_{2}$ caused significant contraction. In the fetus treated with vitamin $\mathrm{A}$ twice, contraction induced by $5 \% \mathrm{O}_{2}$ was significantly greater than in the control group. *Significantly different from the value in the control group.

methacin did not cause significant contraction in the control fetus and the fetus treated with vitamin A once (Fig. 5). In the fetuses treated with vitamin A twice, indomethacin did cause significant contraction.

Noradrenaline-Induced Contraction. The effect of vitamin A treatment on the size of the intracellular $\mathrm{Ca}$ pool was estimated using noradrenaline in the fetuses at 19 and $20 \mathrm{~d}$ of gestation. Noradrenaline-induced contraction in the group

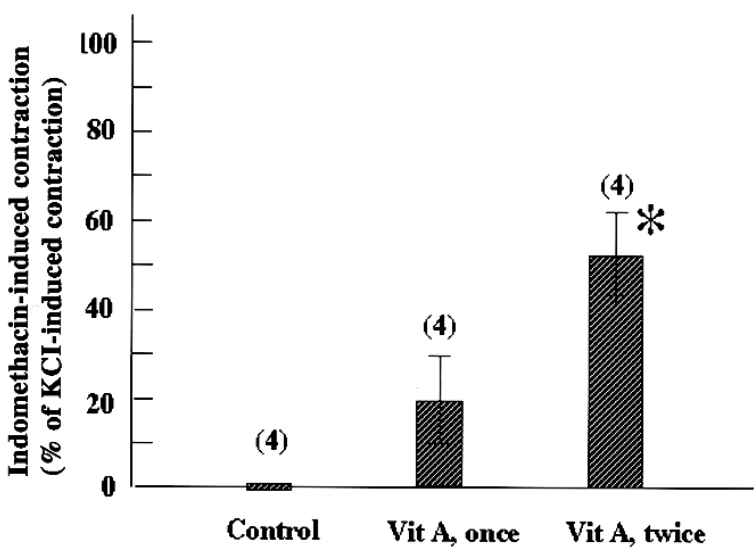

Figure 5. Graph showing the effect of indomethacin on ductal contraction in the fetus at $19 \mathrm{~d}$ of gestation. Indomethacin caused significant contraction only in the fetuses treated with vitamin A twice. *Significant contraction. Number in parenthesis indicates number of the experiments performed.

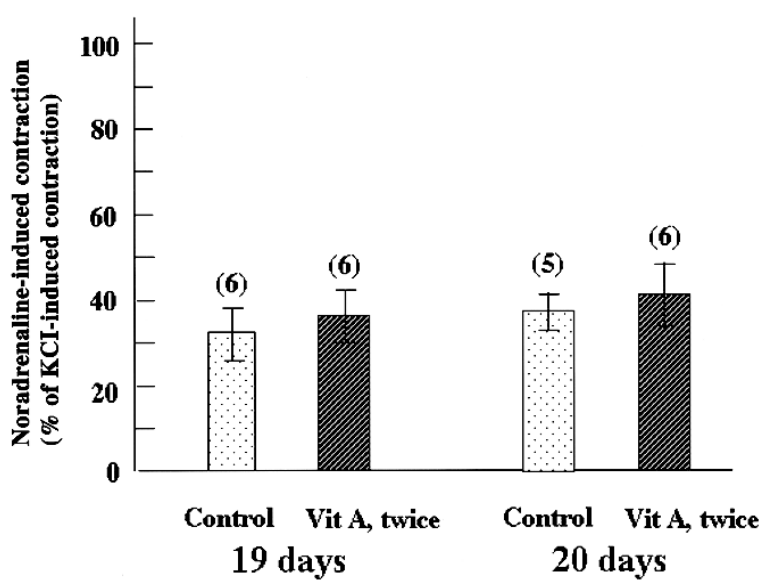

Figure 6. Graph showing the effect of noradrenaline on ductal contraction in the fetus at 19 and $20 \mathrm{~d}$ of gestation. Noradrenaline $\left(10^{-5} \mathrm{M}\right)$-induced contraction was examined in $\mathrm{Ca}$-and $\mathrm{Na}$-free solutions. Noradrenaline-induced contraction in the group treated with vitamin A twice was similar to that in the control group. Number in parenthesis indicates number of the experiments performed.

treated with vitamin A twice was similar to that in the control group (Fig. 6).

$[\text { Ca }]_{i}$ Measurements. The effect of $\mathrm{O}_{2}$ on $[\mathrm{Ca}]_{\mathrm{i}}$ in the ductal tissue was studied in the fetus at $19 \mathrm{~d}$ of gestation. In the control fetus, $30 \%$ and $95 \% \mathrm{O}_{2}$ did not cause a significant increase in $[\mathrm{Ca}]_{\mathrm{i}}$. In the fetus treated with vitamin A twice, $30 \%$ and $95 \% \mathrm{O}_{2}$ caused significant increases in $[\mathrm{Ca}]_{\mathrm{i}}$ (Table $3)$.

The effect of noradrenaline on $[\mathrm{Ca}]_{\mathrm{i}}$ was studied in the fetus at $19 \mathrm{~d}$ of gestation (Table 4). The noradrenaline-induced increases in $[\mathrm{Ca}]_{\mathrm{i}}$ in the control fetus was similar to that in the fetus treated with vitamin A twice. High $\mathrm{KCl}(50 \mathrm{mM})$ increased $[\mathrm{Ca}]_{\mathrm{i}}$ similarly in the control fetus and in the fetus treated with vitamin A (Table 4).

The Role of the Endothelium. The role of the endothelium in the $\mathrm{O}_{2}$-induced contraction was studied in the ductus arteriosus from which the endothelium was removed in the fetuses at 19 and $20 \mathrm{~d}$ of gestation. In the control fetuses at 19 and $20 \mathrm{~d}$ 
Table 3. Effect of $\mathrm{O}_{2}$ on $[\mathrm{Ca}] \mathrm{i}$

\begin{tabular}{|c|c|c|c|c|c|c|c|c|c|}
\hline Groups & Pre-treatment & $n$ & $\begin{array}{c}\text { Baseline } \\
{[\mathrm{Ca}] \mathrm{i}} \\
(\mathrm{nM})\end{array}$ & $\begin{array}{c}{[\mathrm{Ca}] \mathrm{i} \text { at }} \\
30 \% \mathrm{O}_{2} \\
(\mathrm{nM})\end{array}$ & $\begin{array}{c}\text { Net increase } \\
\text { by } 30 \% \mathrm{O}_{2} \\
(\mathrm{nM})\end{array}$ & $\begin{array}{l}{[\mathrm{Ca}] \mathrm{i} \text { at }} \\
95 \% \mathrm{O}_{2} \\
(\mathrm{nM}) \mathrm{Net}\end{array}$ & $\begin{array}{c}\text { Net increase } \\
\text { by } 95 \% \mathrm{O}_{2} \\
(\mathrm{nM})\end{array}$ & $\begin{array}{c}{[\mathrm{Ca}] \mathrm{i} \text { at } 50} \\
\mathrm{nM} \mathrm{KCl} \\
(\mathrm{nM})\end{array}$ & $\begin{array}{c}\text { Net increase } \\
\text { by } \mathrm{KCl} \\
(\mathrm{nM})\end{array}$ \\
\hline 1. 19-day fetus & Control & 5 & $45 \pm 5$ & $45 \pm 5$ & 0 & $45 \pm 5$ & 0 & $68 \pm 4 *$ & $23 \pm 2$ \\
\hline 2. 19-day fetus & Vitamin A (twice) & 6 & $46 \pm 12$ & $55 \pm 13 *$ & $9 \pm 2 \dagger$ & $59 \pm 13 *$ & $13 \pm 1 \dagger$ & $68 \pm 12 *$ & $22 \pm 2$ \\
\hline
\end{tabular}

* Significant increase from baseline.

$\dagger$ Significantly different from the control value.

Table 4. Effect of noradrenaline on $[\mathrm{Ca}] \mathrm{i}$

\begin{tabular}{|c|c|c|c|c|c|c|c|}
\hline Groups & Pre-treatment & $n$ & $\begin{array}{c}\text { Baseline } \\
{[\mathrm{Ca}] \mathrm{i}} \\
(\mathrm{nM})\end{array}$ & $\begin{array}{c}{[\mathrm{Ca}] \mathrm{i} \text { at }} \\
\text { noradrenaline } \\
(\mathrm{nM})\end{array}$ & $\begin{array}{l}\text { Net increase } \\
(\mathrm{nM})\end{array}$ & $\begin{array}{c}{[\mathrm{Ca}] \mathrm{i} \text { at } 50} \\
\mathrm{mM} \mathrm{KCl} \\
(\mathrm{nM})\end{array}$ & $\begin{array}{c}\text { Net increase } \\
(\mathrm{nM})\end{array}$ \\
\hline 1. 19-day fetus & Control & 4 & $45 \pm 9$ & $57 \pm 10^{*}$ & $12 \pm 1$ & $73 \pm 7 *$ & $28 \pm 4$ \\
\hline 2. 19-day fetus & Vitamin A (twice) & 4 & $42 \pm 9$ & $58 \pm 8 *$ & $16 \pm 3$ & $73 \pm 8 *$ & $28 \pm 4$ \\
\hline
\end{tabular}

* Significant increase from baseline value.

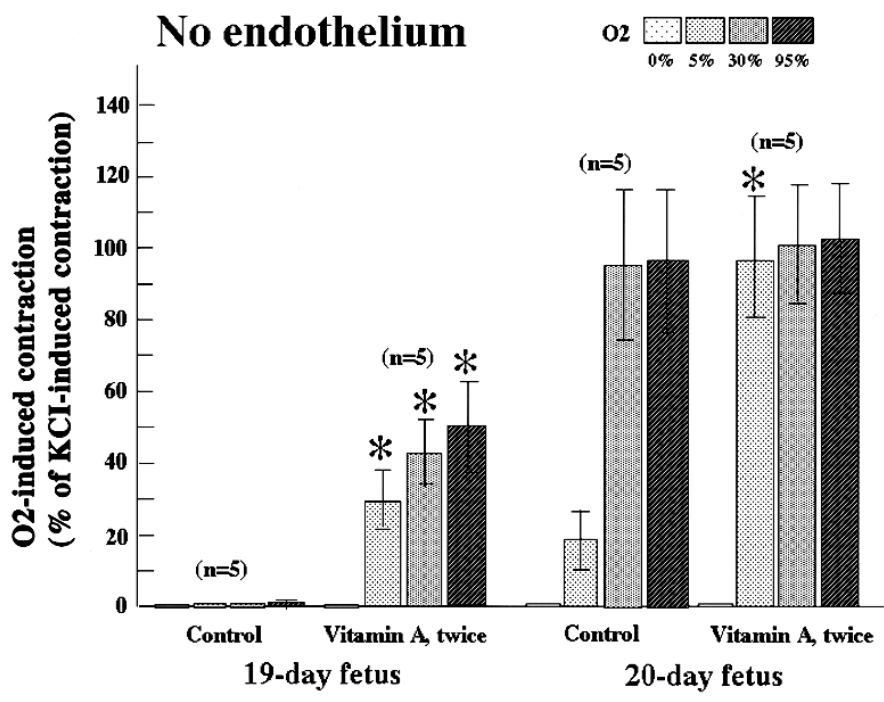

Figure 7. Graph showing the role of the endothelium in the $\mathrm{O}_{2}$-induced contraction in the fetus at 19 and $20 \mathrm{~d}$ of gestation. In the control fetuses at 19 and $20 \mathrm{~d}$ of gestation, removal of the endothelium did not alter the $\mathrm{O}_{2}$-induced contraction. In the fetuses at 19 and $20 \mathrm{~d}$ of gestation treated with vitamin A twice, the $\mathrm{O}_{2}$-induced contraction in the ductus from which the endothelium was removed was not different from that in the ductus in which the endothelium was intact.

of gestation, removal of the endothelium did not alter the $\mathrm{O}_{2}$-induced contraction. In the fetuses at 19 and $20 \mathrm{~d}$ of gestation treated with vitamin $\mathrm{A}$ twice, the $\mathrm{O}_{2}$-induced contraction in the ductus from which the endothelium was removed was not different from that in the ductus in which the endothelium was intact (Fig. 7).

\section{DISCUSSION}

The $\mathrm{O}_{2}$-sensing mechanisms of the ductus arteriosus remain undetermined. Coceani et al. $(1,28-30)$ suggested that cytochrome $\mathrm{P} 450$ is an $\mathrm{O}_{2}$ sensor and interaction of P450 with oxygen might increase endothelin production by the ductal smooth muscle cells, resulting in ductal contraction. Nakanishi et al. (13) hypothesized that $\mathrm{O}_{2}$ might close the ATP-sensitive $\mathrm{K}$ channel. Tristani-Firouzi et al. (14), however, suggested that the voltage-dependent $\mathrm{K}$ channel was responsible for the $\mathrm{O}_{2}$ induced membrane depolarization. $\mathrm{O}_{2}$ may, either directly or mediated by endothelin, cause membrane depolarization of the smooth muscle cells, increase $\mathrm{Ca}$ influx, induce $\mathrm{Ca}$ release from intracellular store sites, increase $[\mathrm{Ca}]_{\mathrm{i}}$, and finally cause ductal contraction.

In the control group in the present study, membrane depolarization, induced by high $\mathrm{KCl}$, increased $[\mathrm{Ca}]_{\mathrm{i}}$ and resulted in ductal contraction even in the preterm fetus at $19 \mathrm{~d}$ of gestation, in which no significant $\mathrm{O}_{2}$-induced contraction was observed. Furthermore, noradrenaline caused significant increases in $[\mathrm{Ca}]_{\mathrm{i}}$ and ductal contraction in this age group, suggesting that the intracellular Ca pool is present even in the preterm fetus at $19 \mathrm{~d}$ of gestation. These data suggest that the contractile system of the DA, from membrane depolarization to increases in $[\mathrm{Ca}]_{\mathrm{i}}$ and muscle contraction, is functioning even in the preterm fetus and only $\mathrm{O}_{2}$-sensing mechanisms are underdeveloped. The data in Fig. 1-4 suggest that the sensitivity to $\mathrm{O}_{2}$ increases with development and vitamin A treatment may accelerate the development of $\mathrm{O}_{2}$-sensitivity.

Kim et al. (11) have shown in near-term fetal rabbits that the expression of the adult-type isoform of smooth muscle myosin heavy chain in the DA was more prominent than in other arteries. They suggested that vascular smooth muscle cells in the DA might be more differentiated than in the other arteries. Colbert et al. (12) showed that endogenous retinoic acid signaling colocalized with advanced expression of the adult type of smooth muscle myosin heavy chain isoform during development of the DA. In the present study, vitamin A treatment did not change the contractile force obtained with $50 \mathrm{mM} \mathrm{KCl}$ in each age group (Table 2). The maximal contractile force obtained with $120 \mathrm{mM} \mathrm{KCl}$ and $10 \mathrm{mM} \mathrm{CaCl}_{2}$ was also similar in the control fetus and the fetus treated with vitamin A. Although changes in myosin isozymes may alter myosin ATPase activity and the rate of actin-myosin cross-bridge cycling (31), the maximal contractile force is determined by the amount of contractile proteins per unit of ductal tissue. Therefore, it is unlikely that vitamin A induced quantitative changes in contractile proteins. In the present study, the effect of vitamin A treatment on myosin isozymes was not evaluated and it remained possible that vitamin $\mathrm{A}$ induced qualitative changes in contractile proteins. Although the developed tension normalized by the length of the vessel increased with age, 
absolute values of contractile force, normalized by the crosssectional area of the preparation, did not change with age (Table 2). This suggests that the amount of contractile proteins per unit cross-sectional area in the preterm fetus is similar to that in the near-term fetus.

One may argue that vitamin A treatment has altered the sensitivity of contractile proteins to $\mathrm{Ca}$ and increased $\mathrm{O}_{2}$ induced contraction in the fetus treated with vitamin $\mathrm{A}$, even though changes in $[\mathrm{Ca}]_{\mathrm{i}}$ were similar in the control fetus and in the fetus treated with vitamin A. In the fetus at $19 \mathrm{~d}$ of gestation, however, ductal contraction was always associated with increases in $[\mathrm{Ca}]_{\mathrm{i}}$ and both $\mathrm{O}_{2}$-induced ductal contraction and increases in $[\mathrm{Ca}]_{\mathrm{i}}$ were observed only in the fetus treated with vitamin A. Furthermore, the degree of contraction obtained by high $\mathrm{KCl}$ and increases in $[\mathrm{Ca}]_{\mathrm{i}}$ were similar in the control fetus and in the fetus treated with vitamin A. Therefore, although the sensitivity of contractile proteins to $\mathrm{Ca}$ was not directly measured in the present study, it is unlikely that the increased sensitivity to $\mathrm{O}_{2}$ in the fetus treated with vitamin A was due to qualitative changes in contractile proteins induced by vitamin A treatment.

In the fetuses at 20 and $21 \mathrm{~d}$ of gestation, treatment with vitamin A did not further alter the degree of contraction induced by $30 \%$ and $95 \% \mathrm{O}_{2}$, most likely because the degree of contraction induced by $30 \%$ to $95 \% \mathrm{O}_{2}$ was close to the maximal contraction that can be achieved by the ductal smooth muscle. In support of this hypothesis, the addition of high $\mathrm{KCl}$ $(120 \mathrm{mM})$ and high $\mathrm{Ca}(10 \mathrm{mM})$ to the oxygenated solution did not further increase the degree of contraction induced by $95 \%$ $\mathrm{O}_{2}$ in these age groups. In the fetus at $19 \mathrm{~d}$ of gestation, which was treated with vitamin A once or twice, $5 \% \mathrm{O}_{2}$ induced a small but significant contraction (Fig. 3). The reason why ductal contraction did not further increase with the increase in $\mathrm{O}_{2}$ concentration (to $30 \%$ to $95 \%$ ) is not clear, but higher $\mathrm{O}_{2}$ concentration might not have further activated processes inducing membrane depolarization. Measurement of the intracellular Ca pool using norepinephrine was performed to determine whether vitamin A treatment alters its size. It must be noted that norepinephrine stimulates not only alpha-adrenergic receptors, but also beta-receptors and increases $\mathrm{Ca}$ influx via $\mathrm{Ca}$ channels (15-17). To eliminate the $\mathrm{Ca}$ influx via the $\mathrm{Ca}$ channel, the effect of norepinephrine was examined in the absence of extracellular $\mathrm{Ca}(16)$. The increase in $[\mathrm{Ca}]_{\mathrm{i}}$ caused by norepinephrine in the fetus treated with vitamin $\mathrm{A}$ was similar to that in the control fetus, suggesting that the size of the Ca pool was similar in the two groups.

In the present study, pretreatment with vitamin $\mathrm{A}$ also augmented indomethacin-induced ductal contraction (Fig. 7). This finding is in agreement with the in situ morphometric data of Momma et al. (9). It is likely that in the control fetuses at $19 \mathrm{~d}$ of gestation, the vasoconstrictive effect of $5 \% \mathrm{O}_{2}$ was not significant and, therefore, inhibition of prostaglandin E2 production by indomethacin did not cause any ductal contraction. In the fetuses treated with vitamin $\mathrm{A}$, however, $5 \% \mathrm{O}_{2}$ had significant vasoconstrictive effect. Thus, the augmented indomethacin-induced contraction in the fetus treated with vitamin A may be, at least in part, due to increased sensitivity to $\mathrm{O}_{2}$ in this group. However, since prostaglandins were not measured directly in the present study, the effect of vitamin A treatment on prostaglandin pathways in the DA remains unclear. Since the location of the $\mathrm{O}_{2}$-sensing mechanism is unknown (4), we performed additional experiments in the endothelium-denuded preparation. The fact that $\mathrm{O}_{2}$-induced contraction was observed in the absence of the endothelium in the control fetus at $20 \mathrm{~d}$ of gestation suggests that an $\mathrm{O}_{2}$-sensing mechanism does not exist in the endothelium. In the fetuses at 19 and $20 \mathrm{~d}$ of gestation treated twice with vitamin $\mathrm{A}$, the $\mathrm{O}_{2}$-induced contraction in the ductus from which the endothelium was removed was not different from that in the ductus in which the endothelium was intact. These data may suggest that vitamin A treatment enhances development of an $\mathrm{O}_{2}$-sensing mechanism, which is present in the vascular smooth muscle cells.

Although precise mechanisms whereby the ductus senses $\mathrm{O}_{2}$ remain unknown, the cytochrome $\mathrm{P} 450$-endothelin pathway (30) and $\mathrm{K}$ channels $(13,14)$ have been implicated. $\mathrm{O}_{2}$ may alter the redox status of the cell and $\mathrm{K}$ channels may be redox-modulated $(32,33)$. The regulation of $\mathrm{K}$ channels by the redox state may differ at different stages of development. Furthermore, many enzymes and ion channels may be involved in an $\mathrm{O}_{2}$-sensing mechanism. It has been shown that retinoic acid, a derivative of vitamin $\mathrm{A}$, can induce a number of genes involved in regulation of smooth muscle differentiation (34, 35). Several investigators have reported that vitamin A or retinoic acid accelerated lung development in the fetal and neonatal rat $(36,37)$. Likewise, it is possible that vitamin A accelerates development of an $\mathrm{O}_{2}$-sensing mechanism in the DA. The effect of vitamin A on the development of putative $\mathrm{O}_{2}$ sensors and effectors, such as the cytochrome P450-endothelin pathway, and/or K channels in the fetal DA has not yet been studied.

Direct extrapolation of the present data to the clinical situation is not easy. Firstly, the degree of involvement of retinoic acid in the maturation of the human DA is not clear. Secondly, the relative importance of $\mathrm{O}_{2}$ sensors and effectors for ductal closure in the rat may be different from that in the human. Nevertheless, we think that administration of vitamin A to the pregnant woman may accelerate the maturation of the fetal DA and its closure after birth even in the premature baby.

In conclusions, the present study suggests that 1 ) in the premature fetus, the contractile system, including membrane depolarization, $[\mathrm{Ca}]_{\mathrm{i}}$ increases and $\mathrm{Ca}$ activation of contractile proteins, is already functioning, but an $\mathrm{O}_{2}$-sensing mechanism is underdeveloped, 2) administration of vitamin A accelerates development of the $\mathrm{O}_{2}$-sensing mechanism of the ductus arteriosus.

\section{REFERENCES}

1. Coceani F, Kelsey L, Seidlitz E 1992 Evidence for an effector role of endothelin in closure of the ductus arteriosus at birth. Can J Physiol Pharmacol 70:1061-1064

2. Heymann MA, Rudolph AM 1975 Control of the ductus arteriosus. Physiol Rev 55:62-78

3. Fay FS 1971 Guinea pig ductus arteriosus. I. Cellular and metabolic basis for oxygen sensitivity. Am J Physiol 221:470-479

4. Abman SH 1996 Oxygen sensing, potassium channels, and the ductus arteriosus [editorial; comment]. J Clin Invest 98:1945-1946

5. Clyman RI, Goetzman BW, Chen YQ, Mauray F, Kramer RH, Pytela R, Schnapp LM 1996 Changes in endothelial cell and smooth muscle cell integrin expression during closure of the ductus arteriosus: an immunohistological comparison of the fetal, 
preterm newborn, and full-term newborn rhesus monkey ductus. Pediatr Res 40:198208

6. Vermillion ST, Scardo JA, Lashus AG, Wiles HB 1997 The effect of indomethacin tocolysis on fetal ductus arteriosus constriction with advancing gestational age. Am J Obstet Gynecol 177:256-259

7. Moise Jr KJ 1993 Effect of advancing gestational age on the frequency of fetal ductal constriction in association with maternal indomethacin use. Am J Obstet Gynecol 168:1350-1353

8. Momma K, Takao A 1987 In vivo constriction of the ductus arteriosus by nonsteroidal antiinflammatory drugs in near-term and preterm fetal rats. Pediatr Res 22:567-572

9. Momma K, Toyono M, Miyagawa-Tomita S 1998 Accelerated maturation of fetal ductus arteriosus by maternally administered vitamin A in rats. Pediatr Res 43:629632

10. Momma K, Takao A 1989 Increased constriction of the ductus arteriosus with combined administration of indomethacin and betamethasone in fetal rats. Pediatr Res 25:69-75

11. Kim HS, Aikawa M, Kimura K, Kuro-o M, Nakahara K, Suzuki T, Kato H, Okamoto E, Yazaki Y, Nagai R 1993 Ductus arteriosus. Advanced differentiation of smooth muscle cells demonstrated by myosin heavy chain isoform expression in rabbits. Circulation 88:1804-1810

12. Colbert MC, Kirby ML, Robbins J 1996 Endogenous retinoic acid signaling colocalizes with advanced expression of the adult smooth muscle myosin heavy chain isoform during development of the ductus arteriosus. Circ Res 78:790-798

13. Nakanishi T, Gu H, Hagiwara N, Momma K 1993 Mechanisms of oxygen-induced contraction of ductus arteriosus isolated from the fetal rabbit. Circ Res 72:1218-1228

14. Tristani-Firouzi M, Reeve HL, Tolarova S, Weir EK, Archer SL 1996 Oxygeninduced constriction of rabbit ductus arteriosus occurs via inhibition of a 4-aminopyridine-, voltage-sensitive potassium channel. J Clin Invest 98:1959-1965

15. Cauvin C, Saida K, van Breemen C 1984 Extracellular Ca2+ dependence and diltiazem inhibition of contraction in rabbit conduit arteries and mesenteric resistance vessels. Blood Vessels 21:23-31

16. Nakanishi T, Gu H, Abe K, Momma K 1997 Developmental changes in contractile system of the mesenteric small artery of rabbit. Pediatr Res 41:65-71

17. Cauvin C, Lukeman S, Cameron J, Hwang O, van Breemen C 1985 Differences in norepinephrine activation and diltiazem inhibition of calcium channels in isolated rabbit aorta and mesenteric resistance vessels. Circ Res 56:822-828

18. Mulvany MJ, Halpern W 1977 Contractile properties of small arterial resistance vessels in spontaneously hypertensive and normotensive rats. Circ Res 41:19-26

19. Nakanishi T, Gu H, Momma K 1996 Effect of acidosis on contraction, intracellular $\mathrm{pH}$ and calcium in the rabbit mesenteric small artery. J Mol Cell Cardiol 28:17151726

20. Nakanishi T, Gu H, Momma K 1997 Developmental changes in the effect of acidosis on contraction, intracellular $\mathrm{pH}$, and calcium in the rabbit mesenteric small artery. Pediatr Res 42:750-757
21. Wang Y, Coceani F 1992 Isolated pulmonary resistance vessels from fetal lambs. Circ Res 71:320-330

22. Coceani F, Liu YA, Seidlitz E, Kelsey L, Kuwaki T, Ackerley C, Yanagisawa M 1999 Endothelin A receptor is necessary for $\mathrm{O} 2$ constriction but not closure of ductus arteriosus. Am J Physiol 277:H1521-H1531

23. Forstermann U, Herttng G, Neufang B 1984 The importance of endogenous prostaglandins other than prostacyclin, for the modulation of contractility of some rabbit blood vessels. Br J Pharmacol 81:623-630

24. Clyman RI, Waleh N, Black SM, Riemer RK, Mauray F, Chen Y 1998 Regulation of ductus arteriosus patency by nitric oxide in fetal lambs: the role of gestation, oxygen tension, and vasa vasorum. Pediatr Res 43:633-644

25. Nakanishi T, Seguchi M, Tsuchiya T, Yasukouchi S, Takao A 1990 Effect of acidosis on intracellular $\mathrm{pH}$ and calcium concentration in the newborn and adult rabbit myocardium. Circ Res 67:111-123

26. Nakanishi T, Seguchi M, Tsuchiya T, Cragoe Jr EJ, Takao A, Momma K 1991 Effect of partial $\mathrm{Na}$ pump and $\mathrm{Na}-\mathrm{H}$ exchange inhibition on $[\mathrm{Ca}] \mathrm{i}$ during acidosis in cardiac cells. Am J Physiol 261:C758-766

27. Armitage P, Berry G 1988 Statistical Methods in Medical Research. Blackwell Scientific Publications, Boston, pp 408-420

28. Coceani F, Kelsey L 1991 Endothelin-1 release from lamb ductus arteriosus: relevance to postnatal closure of the vessel. Can J Physiol Pharmacol 69:218-221

29. Coceani F, Kelsey L, Seidlitz E 1994 Occurrence of endothelium-derived relaxing factor-nitric oxide in the lamb ductus arteriosus. Can J Physiol Pharmacol 72.82-88

30. Coceani F 1994 Control of the ductus arteriosus-a new function for cytochrome P450, endothelin and nitric oxide. Biochem Pharmacol 48:1315-1318

31. Arner A, Malmqvist U 1998 Cross-bridge cycling in smooth muscle: a short review. Acta Physiol Scand 164:363-372

32. Reeve HL, Weir EK 1999 Regulation of ion channels in the ductus arteriosus. In Weir EK, Archer SL, Reeves JT (eds) The Fetal and Neonatal Pulmonary Circulations. Futura Publishing Company, Armonk, NY, pp 319-330

33. Archer SL, Huang J, Henry T, Peterson D, Weir EK 1993 A redox-based O2 sensor in rat pulmonary vasculature. Circ Res 73:1100-1112

34. Blank RS, Swartz EA, Thompson MM, Olson EN, Owens GK 1995 A retinoic acid-induced clonal cell line derived from multipotential P19 embryonal carcinoma cells expresses smooth muscle characteristics. Circ Res 76:742-749

35. Rudnicki MA, Sawtell NM, Reuhl KR, Berg R, Craig JC, Jardine K, Lessard JL, McBurney MW 1990 Smooth muscle actin expression during P19 embryonal carcinoma differentiation in cell culture. J Cell Physiol 142:89-98

36. Whitney D, Massaro GD, Clerch LB 1999 Gene expression of cellular retinoidbinding protein: modulation by retinoic acid and dexamethasone in postnatal rat lung. Pediatr Res 45:2-7

37. Thabaud B, Mercier JC, Dinn-Xuan T, Archer SL 1998 Vitamin A improves survival and lung weight in experimental congenital diaphragmatic hernia. Circulation 98:I-63 